\title{
Construction or Constructing? Some Observations on English Deverbal and Gerundial Nouns
}

\section{ABSTRACT}

English deverbal and gerundial nouns are traditionally analysed as instances of verbal nominalisations with a hybrid syntactic and semantic nature: while predominantly having nominal properties, they display some of the verbal characteristics as well. Using relevant examples from English corpora (BNC, ukWaC, enTenTen13), the paper examines the similarities and differences between the two types of nominalisations with special focus on their syntactic and semantic properties. The paper discusses deverbal/gerundial nouns in relation to the s.c. gerundial cline, which refers to the gradual process of nominalisation as observed in English. The analysis of examples shows that gerundial nouns are typically associated with the eventive interpretation, and that the structure of the nominal phrase headed by a gerundial noun directly reflects the syntactic properties of the verbal root. Deverbal nouns, on the other hand, are typically associated with the result-object interpretation, and the structure of the nominal phrase headed by a deverbal noun is less dependent on the syntactic properties of the verbal root. Despite these apparent differences, corpus data also reveal that the converse is also true: deverbal nouns can be used as gerundial nouns and vice versa.

Keywords: deverbal nouns; gerundial nouns; gerundial cline; nominalisation; nominal phrase; syntax; semantics

\section{Gradnja ali grajenje? $\mathrm{O}$ angleških izglagolskih in glagolskih samostalnikih}

\author{
POVZETEK
}

Angleški izglagolski in glagolski samostalniki so primeri nominalizacij, ki skladenjsko in pomensko kažejo lastnosti tako samostalnikov kot glagolov. S pomočjo relevantnih primerov iz referenčnih angleških korpusov (BNC, ukWaC, enTenTen13) članek obravnava podobnosti in razločke med izglagolskimi in glagolskimi samostalniki. Izglagolski in glagolski samostalniki so obravnavani tudi z vidika postopnosti izglagolskega nominalizacijskega procesa. Razčlemba korpusnih primerov pokaže, da se glagolski samostalniki pogosto rabijo, kadar izražajo dogodkovni pomen. Struktura samostalniške zveze, katere jedro je glagolski samostalnik, jasno odseva skladenjske zahteve glagolskega korena. Nasprotno se izglagolski samostalniki tipično pojavljajo z rezultativnim pomenom. Struktura samostalniške zveze, katere jedro je izglagolski samostalnik, ni več nujno odvisna od skladenjskih zahtev glagolskega korena. Korpusni podatki med drugim pokažejo, da je nasprotno tudi mogoče: izglagolski samostalniki se lahko rabijo kot glagolski in obratno.

Ključne besede: glagolski samostalniki; izglagolski samostalniki; nominalizacija; samostalniška zveza; skladnja; pomenoslovje 


\section{Construction or Constructing? Some Observations on English Deverbal and Gerundial Nouns ${ }^{1}$ 1 Introduction and Basic Assumptions}

The classification of the -ing forms in English has always been a source of controversy among linguists. In traditional grammatical descriptions, verbal -ing forms in the nominal function (1a) have been labelled as gerunds, whereas verbal -ing forms in the adverbial function (1b) have been referred to as participles.

(1) a) I can remember leaving the room and walking in the completely opposite direction to where I should have gone.

b) 'Well, that's odd,' said she, leaving the room.

Despite the fact that the same nominal/adverbial dichotomy can be observed in the case of the infinitive $(2 \mathrm{a}, \mathrm{b})$, no special typological distinction, apart from sub-specifying the infinitival clause w.r.t. its syntactic role (i.e., the adverbial or the nominal infinitival clause), has been drawn in descriptive grammars. As a consequence, several authors have proposed that the -ing forms such as those in (1) be treated as the same category. For example, Quirk et al. $(1985,150)$ call this category the -ing participle, and to distinguish the nominal syntactic function (1a) from the adverbial (1b), the authors (op.cit., ch. 15) resort to the terms nominal -ing clauses and adverbial -ing clauses respectively. Huddleston and Pullum (2002, 81-83) label this category as the gerund-participle form of the verb.

(2) a) Both of them asked me to leave the room for half an hour.

b) I slowly turned to leave the room, and then, for some unknown reason, abruptly stopped.

The present paper, however, does not adopt these uniform classifications, but follows the traditional analysis, in which the verbal -ing forms used nominally are labelled as gerunds (1a), and those used adverbially as participles (1b).

It has been observed and discussed in the relevant literature (Chomsky 1970, Malouf 1998, Hudson 2000, Alexiadou 2001 a.o.) that in English, gerundial structures display different syntactic patterning (3), in which (3b) is the most verbal and the least nominal, and, conversely, $\left(3 \mathrm{c}, \mathrm{c}^{\prime}\right)$ the least verbal and the most nominal. The gradience exemplified in $(3 \mathrm{~b}-\mathrm{c})$ has been referred to as the Gerundial Cline (Dienhart and Jakobsen 1985) or the Deverbalization Hierarchy (Malouf 1998). Examples (3a) and (3d) simply mark the endpoints of the continuum, i.e., the verbal and nominal endpoint respectively.

(3) a) His ego [...] ensured that he completely failed to understand the difference.

b) Today that happened with my Mum unexpectedly quoting Dickens at me, and my completely failing to get the reference.

c) And believe that his case highlights the failing of the criminal justice system.

c) Robertson was justly appreciated for his account of the failings of the feudal system.

d) Hamilton's poor judgement of when to intervene led to complete failure and needless loss.

I would like to thank the two anonymous reviewers for their insightful comments. Needless to say, all errors remain my own. 
Filling the argument position in (3a), the subordinate finite clause superficially behaves like a nominal (i.e., nominal subordinate clause); however, internally, it has only clausal properties. The verb failed displays tense/aspect/mood/voice distinction, selects arguments/adjuncts, and thus provides the event structure of the clause (cf., Grimshaw 1990, 26). Similarly, both gerundial clauses in (3b) are nominal externally (i.e., complements to the preposition with), whereas internally, the gerundial forms quoting and failing behave exclusively as verbs: they select adjuncts (e.g., unexpectedly, completely) and direct objects (e.g., Dickens). The presence of the possessive pronoun in my completely failing does not indicate the nominal structure, since the possessive is not interchangeable with the definite article ( ${ }^{*}$ the completely failing ...) as is the case with true nominal phrases in English, for example, his/the failure to please (for details see Huddleston and Pullum 2002, 1189ff). Examples (3c, c') mark the boundary between gerundial structures that are externally nominal but internally verbal, and those that are nominal both externally and internally in syntax. In (3c, c'), the gerundial form failing no longer functions as a predicator, and consequently cannot select objects, complements, and adjuncts. It heads the nominal phrase with typical nominal modifiers: the determiner, adjectival premodification and of-phrase postmodification. Finally, (3d) contains the deverbal noun failure which is associated with syntactic nominal properties only. The labelling of the intermediate stages on the cline varies from author to author, so for clarity's sake, Table 1 summarizes different terminological proposals.

TABLE 1. The gerundial cline and different terminological solutions.

\begin{tabular}{|l|l|l|l|}
\hline Author & $(3 \mathrm{~b})$ & $\left(3 \mathbf{c}, \mathbf{c}^{\prime}\right)$ & $(3 \mathrm{~d})$ \\
\hline Chomsky (1970) & gerundive nominal & “mixed” form & derived nominal \\
\hline Quirk et al. (1985) & gerund & verbal noun & deverbal noun \\
\hline Hudson (2000) & gerund & \multicolumn{2}{|l|}{ nominalization } \\
\hline Alexiadou (2001) & gerund & mixed nominalization & derived nominal \\
\hline $\begin{array}{l}\text { Huddleston and } \\
\text { Pullum (2002) }\end{array}$ & gerund-participle form & gerundial noun & deverbal noun \\
\hline present paper & gerund & gerundial noun & deverbal noun \\
\hline
\end{tabular}

Leaving the analysis of the gerund (i.e., gerundial structures with only the internal properties of the verb - (3b)) aside, the present paper focusses on the similarities and differences between gerundial and deverbal nouns with the help of attested examples taken from three English referential corpora (BNC, $\mathrm{uKWaC}$ and enTenTen13).

\section{Gerundial and Deverbal Nouns}

Perhaps the most obvious difference between the two categories is their morphological makeup. While they both share the same verbal root, the gerundial nouns are formed by adding the nominalising suffix -ing to the verbal root, whereas the deverbal nouns are formed by means of different derivational morphemes, such as -age, -al, -ation, -ment, and zero derivation morpheme (i.e., conversion), for example, coverage, refusal, exploration, arrangement, and attempt respectively (Quirk et al. 1985, 1550ff; Greenbaum 1992, 1085). In addition, these authors point out that gerundial nouns (in their terminology: verbal nouns) are distinct from deverbal nouns ending in -ing that have no verbal force (Greenbaum 1992, 1085). Consider examples (4a), in which the -ing is part of a deverbal noun (concrete, countable noun), and (4b), in which the -ing is part of a gerundial noun (abstract, uncountable noun). 
(4) a) Most of the buildings of Bath all have one thing in common, they are all built of Bath Stone.

b) 1878 saw the building of the Tay Rail Bridge, which collapsed with the loss of 75 lives.

It seems that the proposed distinction between gerundial nouns and (deverbal) nouns ending in -ing builds on the fact that building in (4a) has no verbal properties/force, and it is fully nominalised, which is directly reflected in its concreteness and countability. On the other hand, building in (4b), despite syntactically functioning as a noun, has not been fully nominalised, since it still describes the event of building, and consequently, has a non-concrete referent. This incomplete process of nominalisation leads to the noun being uncountable and abstract.

It is questionable, however, whether countable/uncountable, concrete/abstract, and event/object interpretation dichotomies can be considered reliable diagnostics for distinguishing gerundial nouns from deverbal nouns, because deverbal nouns can also be associated with uncountability, abstract meaning, and/or event interprentation (4c). The reverse is also true: a gerundial noun (4d) can be associated with countability (i.e., pluralisation), concreteness, and/or non-event interpretation, a point already highlighted by Quirk et al. $(1985,1289 \mathrm{ff})$ :

(4) c) There will not be full discussion/*discussions of the proposal or waste management policies and strategies. ${ }^{2}$

d) Kevin managed to keep the group under control, resulting in three sightings of at least two Yellow Rails.

Therefore, the subsequent sections of the paper will examine different properties of English gerundial and deverbal nouns with special focus on the event vs. non-event and concrete vs. abstract distinction.

In a more theory-oriented approach to gerundial and -ing nouns (cf., Chomsky and Halle 1968, and the Distributed Morphology framework as postulated by Halle and Marantz 1993, Halle 1997, Marantz 1997 a. o.), the difference between the two is seen as a reflex of different syntactic derivations in which the nominalising suffix is inserted. Building on these assumption, Marvin (2005) argues that in the case of gerundial nouns (such as twinkling 'the event of twinkling'), the nominalising suffix -ing is added to the verbal element twinkl-, whereas in the case of -ing nouns (such as twinkling 'an instant') the nominalising suffix -ing is added directly to the unspecified lexical root. ${ }^{3}$ The difference may also appear in the pronunciation: /twinəklın/ for the gerundial noun, and /twinklin/ for the -ing noun. Since the present paper is more usage-oriented, this line of analysis will not be pursued further.

\subsection{Deverbal Nouns}

It has long been observed (cf., Grimshaw 1990, Alexiadou 2001) and also well-proven crosslinguistically (Van Hout 1991, Picallo 1991, Sleeman and Brito 2010 a.o.) that deverbal nouns allow at least two distinct semantic interpretations: the event-process (5a), and the result-

Abstract deverbal nouns such as discussion, sleep, swim, etc. become countable when they represent an instance of the abstract concept. Huddleston and Pullum (2002, 337ff) refer to this phenomenon as event instantiations. Consider:

(i) The later phase of anti-Jacobin patriotism was distinct from earlier discussions of obedience to a governor.

(ii) The swimmers were ordered to their marks and the gun set off one of the paramount swims of the meet.

3 This is a very simplified explanation for the purpose of illustration only. What Marvin (2005) originally claims is that in the case of gerundial nouns the nominalising suffix is added to the root twinkl-which is spelt-out at $v \mathrm{P}$, whereas in the case of -ing nouns the nominalising suffix is attached to the unspecified root directly before it is spelt-out. 
object interpretation (5b). There are, however, two opposing views as to what constitutes the object interpretation. For some authors (e.g., Grimshaw 1990, Van Hout 1991), the object interpretation is obtained as soon as the deverbal noun no longer has the event interpretation, but is interpreted as the result of the event. For example, construction in (5b) is the result (i.e., the end-product) of what Greg or Egan have constructed. It could be roughly paraphrased as "a construct" or "a design". The end-product could either be an abstract (5b) or a physical object (5c). To others (e.g., Quirk et al. 1985, Greenbaum 1992, ${ }^{4}$ Sleeman and Brito 2010) the object interpretation is understood in a narrower sense: a deverbal noun has an object interpretation if it describes a concrete object (5c). To distinguish between these two categories, I will refer to the former type of the object interpretation as the result-object interpretation, and the latter as the entity-object interpretation. Throughout the paper, if not stated otherwise, the object interpretation is understood in its broader sense.

(5) a) The other parts of our premises, the refurbishment of the Examination Halls and the construction of another new building are being designed by the architects from the HLM practice. (event)

b) The More manuscript is important to my argument because it is an actual manuscript from the period, rather than some inferential construction by Greg or Egan of what a manuscript should be like.

(result-object)

c) His constructions are altogether less like painting or sculpture in their effect than one might have guested.

(entity-object)

Several authors (Grimshaw 1990, Alexiadou 2001 a.o.) have proposed that the event vs. object interpretation distinction bears direct consequences for the pluralisation of deverbal nouns: while in the object readings the pluralisation of deverbal nouns is possible, this is not the case with the deverbal nouns with the event reading. Other authors (Krifka 1989 a.o.) argue that the pluralisation of the noun does not depend on the type of the interpretation but on the verbal root; namely, only nouns derived from telic verbs allow pluralisation. Examples (6) below show that the situation is far more complex, and that neither proposal can be fully adopted, which renders the pluralisation criterion unreliable. ${ }^{5}$

(6) a) Yoshizaki denied having witnessed the executions of prisoners at grave B' as his attention was concentrated on the macabre drama at grave $A$ '. (telic root, event, plural)

b) Many nations go through periodic destructions of their heritage, which they later come to regret bitterly. (telic root, event, plural)

c) Together and in turns they guide us through the petty annoyances of being somewhere in the broad general neighbourhood of fifty. (atelic root, event(statal), plural)

Another interesting phenomenon concerning deverbal nouns is that the links between the verbal root and its theta role selectional properties (i.e., syntactic valency, cf., Booij 2005, 214ff) can still be traced. The agent participant can be expressed either by the genitive NP ( $7 \mathrm{a})$ or the byphrase $(7 \mathrm{~b})$, whereas the thematic participant is expressed by the of-phrase $(7 \mathrm{a}, \mathrm{c})$. In the case of object deverbal nouns, the postmodifying of-phrase can also denote an agentive participant (7d).

Quirk et al. (1985), Greenbaum (1992) do not make this claim explicitly, but this conclusion can be drawn from their analysis of deverbal nouns (see above).

5 Since the pluralisation process of deverbal nouns is not the focus of the paper, the issue will not be discussed in more detail. For detailed discussion see Sleeman and Brito (2010); Bauke (2014), and references cited therein. 
For some authors (e.g., Van Hout 1991) the interpretation of the postmodifying of-phrase is crucial for determining the nominal status of the deverbal noun: if the postmodifying of-phrase no longer pertains to the thematic participant but to the agent/author participant instead, then the deverbal noun has completely lost its verbal character and is fully nominalised.

(7) a) His refusal of amputation of his leg resulted in his death. (He refused the amputation)

b) Democrats reacted angrily to a refusal by the Republican majority to consider an alternative text. (=The Republican majority refused to consider...)

c) The strenuous refusals of order and meaning of Foucault and his school are exhausting and circular. (=to refuse the order and the meaning...)

d) That the house is still being used today by Tony Blair is down to the refusal of first-ever PM Robert Walpole to accept the house as a personal gift. (=first-ever PM Robert Walpole refused to accept).

Another factor concerning the gradual transition of the deverbal nouns on the verb-to-noun continuum toward the nominal endpoint is the obligatory presence of the participants that are required by the selectional properties of the verbal root (for details and theoretical considerations cf. Alexiadou 2001; Sleeman and Brito 2010 a.o.). Consider (8a,b), in which the sentences become unacceptable if the thematic of-phrase is not explicitly stated (8a), or is contextually non-retrievable (8b). In (8c) the of-phrase is completely absent, but can be optionally added to the deverbal noun. In the latter case, it can either express the thematic participant (8d) or the agentive participant (8e).

(8) a) Instead, we present below a selection * (of the contributions), edited for brevity, at and immediately after the conference.

b) *(As part of a documentary for BBC2, Whitby and a crew of 120 brawny Britons assembled a replica of the Great Trilithon, the largest Stonehenge unit: two upright 40-ton stones with a 10-ton rock stacked across them.) The construction took a mere five days.

c) Durham University has secured the title of 'University of the Year' in the new Sunday Times annual guide to universities. The award was welcomed with delight and enthusiasm by ViceChancellor, Sir Kenneth Calman, as an accolade for staff and students whose work is at the heart of the performance, quality and wider recognition that the title represents.

d) The principal item of interest in the concert was the performance of a Commemoration Ode in memory of the Prince Consort, the words being written by $\mathrm{Mr}$ Walter Maynard, [...], with the music composed by Signor Arditi.

e) When I was in New York almost two years ago I was very impressed by the performance of Denis Quilley in the Broadway production of the musical play Irma La Douce.

Taking into consideration all of the presented characteristics of deverbal nouns, it can be concluded that the class deverbal nouns, despite its representing the final stage of the deverbalization hierarchy (cf., (3)), does not constitute a monolithic syntactic category, but displays another verb-to-noun gradation on the micro level (9b): 
(9) a) macro level: $(\mathrm{V} \rightarrow \mathrm{N})$ :

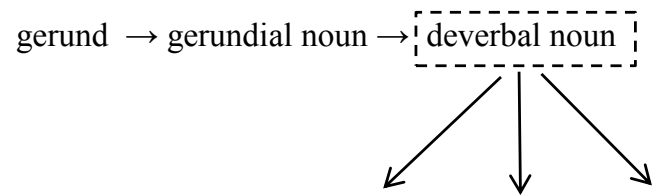

b) micro level: $(\mathrm{V} \rightarrow \mathrm{N})$ :

stage $1 \rightarrow$ stage $2 \rightarrow$ stage 3

At the most verbal stage at the micro level, stage 1 (e.g., (8a)), the deverbal noun still carries the meaning of the event of X. In addition, the underlying selectional properties of the verbal root can be clearly observed, as the presence of the obligatory thematic participant in the form of the of-phrase is required. The agentive participant is always optional, and can be expressed by the genitive or the by-phrase. At stage 2 (e.g., $(8 \mathrm{~d}, \mathrm{e})$ ), the deverbal noun becomes more nominal in the sense that the thematic participant of the lexical root becomes optional. In addition, the of-phrase can be either associated with the thematic participant (verbal property) or with the agentitve participant (nominal property) - compare ( $8 \mathrm{~d}, \mathrm{e})$ respectively. At the final stage, stage 3 , the deverbal noun has lost all of its verbal properties, and has a very strong (entity-)object interpretation $((5 \mathrm{~b}, \mathrm{c}))$. The analysis also shows that the pluralisation factor does not play a key role in determining the stage of the deverbal nouns, since some deverbal nouns belonging to any stage at the micro level can be pluralised (cf., (6)). Finally, it is noteworthy to point out again that the gradation in $(9 \mathrm{c})$ does not take the concreteness criterion to be a conditio sine qua non for the object interpretation at stage 3 (see above and examples $(5 \mathrm{~b}, \mathrm{c})$ ).

\subsection{Gerundial Nouns}

All of the properties of the deverbal nouns discussed and exemplified in the previous section can be observed with gerundial nouns. ${ }^{6}$ To start with different possible meanings, gerundial nouns allow the event and object interpretations:

(10) a) This is an area I have more personal knowledge of, and can remember the demolishing of Hyde Park flats, notorious high rise estates on the hill crests above the town centre.

(event)

b) As a result of the economic plundering of Belgium between 1940 and 1944 the damage suffered amounted to 175 billions of Belgian francs. (event)

c) As is clear from the above, both of those issues formed part of the key failings of the UN in Rwanda. (object)

d) The UK Government will not support a private members bill which includes provisions subject to the Convention without the agreeing with the Scottish Executive that it will seek the consent of the Scottish Parliament to the inclusion of those provisions in the UK Bill.

(result-object)

Even though it is difficult to find examples of gerundial nouns with corresponding deverbal nouns that take the plural ending, the rare corpus occurrences suggest that pluralisation process is affected by neither the interpretation of the gerundial noun (event vs. object) nor the aspectual specification of the root (telic vs. atelic), which again renders the pluralisation criterion unreliable:

(11) a) Amidst these pillagings and depredations of the Scots, earl Gospatric ... made a furious plundering attack upon Cumberland.

(telic root)

For better comparison, the paper discusses only those gerundial nouns that have corresponding deverbal nouns, for example, demolishing $\sim$ demolition, plundering $\sim$ plunder, failing failure, arriving - arrival. 
b) I became more like an assigned driver to him and I did several drivings for him on different jobs that he did.

(atelic root)

c) Then Dan O'Connell arose with his emancipation and repale cries, and then instead of Orange processions and walkings, there were Papist processions and mobs, which made me afraid to stir out, lest knowing me for an Orange fiddler... (atelic root)

As is the case with deverbal nouns, the root of the gerundial noun can preserve its theta role selectional properties. The agent participant can be expressed either by the genitive NP (12a) or the by-phrase (12b), and the thematic participant by the of-phrase (12c). A shift in meaning of the postmodifying of-phrase can also be observed: it may either refer to the thematic participant (12c) or the agent/author participant (12d) of a transitive verb. It has to be pointed out, however, that this shift is extremely untypical with the gerundial nouns, and the corpus data reveal that the postmodifying of-phrase almost exclusively pertains to the thematic participant. The only exception to this generalisation seems to be intransitive verbs, both unergative (12e) and unaccusative verbs $(12 \mathrm{f}){ }^{7}$

(12) a) Despite the horrific absence of Deller's destroying of Bristow in the 1983 final, it's easy to guess that Lim's peerless achievement will win, and the latest results show this. (Deller destroyed Bristow ...)

b) There was more dancing $[. .$.$] , midnight swimming by a brave few, ... (A few brave ones$ swam ...)

c) These can be used for functions or for the performing of civil marriage services. (... to perform civil marriage services)

d) Therewith, the EZLN's consideration on the performing of Mexican press is embodied in the following Marcos'statement: ... (Mexican press performs ...)

e) Tuberculosis is a chronic bacterial disease which is generally transmitted through the coughing and sneezing of an infected person. (An infected person coughs and sneezes)

f) In 1995 he worked from Sarajevo for the newspaper Avvenire documenting the first stage of peace during the arriving of the IFOR forces. (The IFOR forces arrived)

Gerundial nouns are also similar to deverbal nouns in that they display a gradience w.r.t. the obligatory presence of the participants required by the selectional properties of the verbal root. The well-formedness of $(13 \mathrm{a}, \mathrm{b})$ depends on the presence of the thematic of-phrase, be it explicitly stated (13a), or contextually implied (13b). In (13c) the thematic of-phrase is completely absent, but can be optionally added to the noun (13d).

(13) a) Following the demolishing of Ramore Green there was a promise that replacements would be built.

b) One man was killed and another injured at Kedington when a wall at a culvert between the workhouse gates and the mill which they were demolishing fell on them. Messrs Mason, builders of Haverhill were instructed to proceed with the work of renewal. A bricklayer and three labourers were engaged in the demolishing, two arches which had been supported by the centre wall had been removed.

While unergative verbs lack the thematic participant altogether, the surface subject of the unaccusatives has been standardly analysed as the thematic participant (i.e., the internal argument) rather than the agentive participant ever since Perlmutter's (1978) seminal work on the classification of intransitive verbs. 
c) Nowadays, at least in more civilised countries, we do not let armies rampage for booty. We leave the pillaging to men in suits, and we don't call it pillaging any more. We call it economic development.

d) About 90 patients confined to bed remained in the hospital, and 9 members of the staff had bidden in the chimney flues, and thus avoided expulsion. That same day the plundering and demolishing (of the buildings) was begun.

To sum up, it seems that at the micro level (14b), the class of gerundial nouns also displays a gradience scale very similar to that of the deverbal nouns.

(14) a) macro level $(\mathrm{V} \rightarrow \mathrm{N})$ :

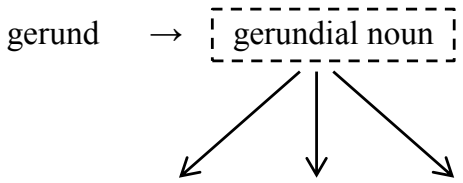

b) micro level $(\mathrm{V} \rightarrow \mathrm{N})$ :

stage $1 \rightarrow$ stage $2 \rightarrow$ stage 3

At the most verbal stage, stage 1 , the gerundial noun still conveys the eventive meaning and is modified by the thematic participant as required by the selectional properties of the verbal root ((12c), (13a)). The agentive participant is always optional, and can be expressed by the genitive or the $b y$-phrase. At stage 2 , the gerundial noun is more nominal, since the thematic participant of the verbal root is no longer required (13c, d). At stage 3 , the gerundial noun is completely nominalised and has a very strong (entity)-object interpretation $((10 c, d))$.

\section{Discussion}

At this point it is first necessary to address the relative position of gerundial and deverbal nouns on the gerundial cline. Traditional approaches (cf., sections 1,2) suggest that gerundial nouns are closer to the verbal endpoint, whereas deverbal nouns are nearer to the nominal endpoint (15a). In other words, gerundial nouns are less nominal than deverbal nouns, and hence represent an intermediate stage between gerunds and deverbal nouns. The corpus data as well as the analysis presented herein show that this assumption is correct only to some extent, and suggest that these two types of nouns can cover the same section of the gerundial cline. Thus, gerundial and deverbal nouns should be seen as belonging to two partly overlapping sections of the gerundial cline rather than two separate sections (15b). Despite the fact that this shared gerundial/deverbal section is close to the nominal endpoint of the cline, there is a variation within the section as to the relative nominal strength of gerundial and deverbal nouns. At the most nominal point (stage 3 ), both types of nouns receive the result-object interpretation, and no direct mapping between the selectional properties of the verbal root and the structure of the nominal phrase is required for the well-formedness of the nominal phrase (e.g., (5c), (7d), (8c), (13c)). On the other hand, at the most verbal point (stage 1), the two types of nouns preserve the event interpretation. In addition, the well-formedness of the nominal phrase depends on the selectional properties of the verbal root: the thematic participant is obligatorily realised by the postmodifying of-phrase, and the agentive participant is never obligatory but may either be expressed by the genitive or the $b y$-phrase (e.g., (5a), (8a), (10a), (12a), (13a)). 


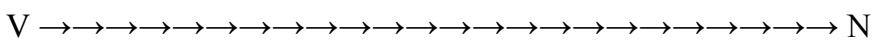

a) gerund $\quad \rightarrow \quad$ gerundial noun $\quad \rightarrow \quad$ deverbal noun

b)

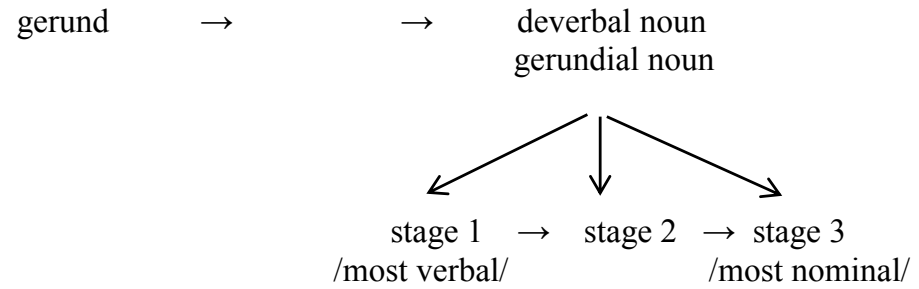

The claim that both deverbal and gerundial nouns cover the same section of the cline can be easily supported by examining the corpus data which reveal strong parallels between the two types of nouns:

Stage (1):

a) I remember the demolition of the ancient structure, and on taking down the more modern case of Norman masonry the Roman appeared, full in view. $\rightarrow$ deverbal noun

b) $I[\ldots]$ can remember the demolishing of Hyde Park flats, ... $\rightarrow$ gerundial noun Stage (2):

c) It was my intention to do the performance and walk away, hoping that perhaps there would be a discussion afterward or a review in the paper. $\rightarrow$ deverbal noun

d) Christopher Nolans route, in my opinion, was nearly flawless, the performing, as many others have stated, superb, and the particular visuals, amazing. $\rightarrow$ gerundial noun

Stage (3):

e) Peter Dyson outlined some of the successes and failures of the UN and considered it ironic that, at the height of the bombing of Afghanistan the Nobel prize had been awarded to the UN and to Secretary-General Kofi Annan. $\rightarrow$ deverbal noun

f) In 1999, two inquiries were released into the infamous peacekeeping disasters of Rwanda and Srebrenica, exploring the failings of the UN system and its Member States and offering recommendations for reform.

$\rightarrow$ gerundial noun

Examples like those in (16) may raise a question as to why English displays two different categories for covering the same syntactic/semantic field. A possible answer could be sought in morphological and etymological analyses. First, as has been observed by many authors (e.g., Chomsky 1970, Bauer 1983), the -ing suffix is still productive in English, whereas most of the deverbal suffixes are no longer productive. As a result, to form a nominal from a verb that has no deverbal counterpart, the nominalising -ing suffix is the only option for the noun formation (cf., Quirk et al. 1985, 1289ff). Second, the meaning of the derived nominals but not gerundial nouns is often idiosyncratic: the dominant meaning of the derived nominal may not be straightforwardly linked with the dominant meaning of the verb (e.g., to establish vs. 
the establishment). ${ }^{8}$ The semantic idiosyncratism can also result from different etymological development. For instance, in some cases, the verb and its corresponding deverbal noun are both loan words - consider the verb to reside and the deverbal noun residence, which come from the Middle French verb reside and the Old French noun residence respectively (Online Etymological Dictionary 2016; Bauer 1983, 79). Consequently, to preserve the dominant meaning of the verb when forming nominalisations, the non-idiosyncratic gerundial form is selected instead of the deverbal noun.

At the end, it has to be stressed, however, that there is still a clear preference as to which type of the noun is selected at a given stage. The gerundial nouns predominantly cover stage 1 , meaning that the noun is typically interpreted as eventive and that the selectional properties of the verbal root are directly reflected in the structure of the nominal phrase. At stages 2 and 3, the number of occurrences of the gerundial nouns gradually drops. The converse seems to be true of deverbal nouns: the number of their occurrences rises from stage 1 to stage 3 .

\section{Conclusion}

Comparing relevant examples from English corpora, the present paper discusses syntactic as well as semantic similarities and differences between gerundial and deverbal nouns. The findings suggest that with respect to their syntactic and semantic properties the boundaries between these two nominal categories are blurred, and there is an observable overlap in their usage. Gerundial and deverbal nouns can both (i) allow event and result-object interpretation, (ii) manifest the theta-role selectional properties of the verbal root, (iii) take the plural ending.

Despite these shared properties, the corpus data clearly show that there is a strong preference as to which type of the nominals is selected in practical usage. Gerundial nouns typically occur with the event interpretation, and their obligatory modifiers are determined by the selectional properties of the verbal root. Deverbal nouns, on the other hand, are frequently associated with the result-object interpretation, and the syntactic structure of nominal phrases headed by deverbal nouns is less dependent on the selectional properties of the verbal root.

\section{References}

Alexiadou, Artemis. 2001. Functional Structure in Nominals. Nominalization and Ergativity. Amsterdam/ Philadelphia: John Benjamins Publishing Company.

Bauer, Laurie. 1983. English Word-formation. Cambridge: Cambridge University press.

Bauke, Leah S. 2014. Symmetry Breaking in Syntax and the Lexicon. Amsterdam/Philadelphia: John Benjamins Publishing Company.

Booij, Geert. 2005. The Grammar of Words. Oxford: Oxford University Press.

Castairs-McCarthy, Andrew. An Introduction to English Morphology. Edinburgh: Edinburgh University Press.

Chomsky, Noam. 1970. "Remarks on Nominalization." In Readings in English Transformational Grammar, edited by Roderick A. Jacobs, and Peter S. Rosenbaum, 184-221. Waltham, Mass.: Ginn and Company.

Chomsky, Noam, and Morris Hale. 1968. The Sound Pattern of English. New York: Harper and Row.

This is a slight overgeneralisation since gerundial nouns may also display semantic and grammatical idiosyncrasies (cf., Castairs-McCarthy 2002, 51), but such occurrences are not as typical as those of deverbal nouns (cf., Grimshaw 2011). 
Dienhart, John M., and Leif Kvistgaard Jakobsen. 1985. “On Clauses, Syntagms, and the English Gerund.” Journal of English Linguistics 18(2):127-52. doi:10.1177/007542428501800203.

Greenbaum, Sidney. 1992. "Verbal Noun.” In The Oxford Companion to the English Language, edited by Tom McArthur, 1085. Oxford/New York: Oxford University Press.

Grimshaw, Jane. 1990. Argument Structure. Cambridge, Mass.: MIT Press.

—. 2011. "Deverbal Nominalization." In Semantics: An International Handbook of Natural Language Meaning, Vol. 2, edited by Klaus Von Heusinger, Claudia Maienborn, and Paul Portner, 1292-313. Berlin/Boston: Walter de Gruyter.

Halle, Morris. 1997. “Distributed Morphology: Impoverishment and Fission.” In MIT Working Papers in Linguistics 30:425-49.

Halle, Morris, and Alec Marantz. 1993. "Distributed Morphology and the Pieces of Inflection.” In The View from Building 20, edited by Ken Hale, and Samuel J. Keyser, 111-76. Cambridge, Mass.: MIT Press.

Huddleston, Rodney, and Geoffrey K. Pullum. 2002. The Cambridge Grammar of the English Language. Cambridge: Cambridge University Press.

Hudson, Richard. 2000. “Gerunds and multiple default inheritance.” UCL Working Papers in Linguistics 12:417-49.

Krifka, Manfred. 1989. "Nominal Reference, Temporal Constitution and Quantification in Event Semantics." In Semantics and Contextual Expressions, edited by Renate Bartsch, Johan van Bentem, and Peter van Emde Boas, 75-115. Dordrecht: Foris.

Malouf, Robert P. 1998. "Mixed Categories in the Hierarchical Lexicon.” PhD diss. Stanford University.

Marantz, Alec. 1997. "No Escape from Syntax: Don't Try Morphological Analysis in the Privacy of Your Own Lexicon." In Proceedings of the 21st Annual Penn Linguistics Colloquium, edited by Alexis Dimitriadis, Laura Siegel, Clarissa Surek-Clark, and Alexander Williams, 201-25.

Marvin, Tatjana. 2005. "English Syllabification and Schwa-Insertion: from the Sound Pattern of English to the Notion of Phase." Linguistica 45:97-106.

Online Etymological Dictionary. 2016. Accessed August 15, 2016. http://www.etymonline.com/.

Perlmutter, David. 1978. "Impersonal Passives and the Unaccusative Hypothesis." Proceedings from the Fourth Annual Meeting of the Berkeley Linguistics Society, 157-89. Berkeley, CA: Berkeley Linguistics Society.

Picallo, Carme M. 1991. "Nominals and nominalizations in Catalan." Probus 3:279-316. doi:10.1515/prbs.1991.3.3.279.

Quirk, Randolph, Sidney Greenbaum, Geoffrey Leech, and Jan Svartvik. 1985. A Comprehensive Grammar of the English Language. Harlow: Longman.

Sleeman, Petra, and Ana Maria Brito. 2010. "Nominalization, Event, Aspect and Argument Structure: A Syntactic Approach.” In Argument Structure and Syntactic Relations, edited by Maia Duguine, Susana Huidobro, and Nerea Madariaga, 113-29. Amsterdam/Philadelphia: John Benjamins Publishing Company.

Van Hout, Angeliek. 1991. "Deverbal Nominalization, Object Versus event Denoting Nominals: Implications for Argument and Event Structure." In Linguistics in the Netherlands 8, edited by Frank Drijkoningen, and Ans M. C. van Kemenade, 71-80. Amsterdam/Philadelphia: John Benjamins Publishing Company. doi:10.1075/avt.8.10hou.

\section{Corpora}

BNC. The British National Corpus. 2010. Accessed September 14, 2016. https://the.sketchengine.co.uk/. enTenTen. English Web Corpus. 2013. Accessed August 15, 2016. https://the.sketchengine.co.uk/.

UkWaC. Web-derived (Domain.uk) Corpus. n.d. Accessed August 15, 2016. https://the.sketchengine.co.uk/. 